\title{
Chorioangioma of Placenta
}

\author{
Khatri $\mathbf{R}^{1}$, Manandhar $\mathbf{R}^{2}$, Pradhan $\mathbf{N}^{3}$, Manandhar $\mathbf{B}^{4}$, Rawal $\mathbf{S}^{5}$
}

${ }^{1}$ Dr Ratna Khatri, ${ }^{2}$ Dr R ita Manandhar, ${ }^{3}$ Dr Neelam Pradhan, ${ }^{4}$ Dr Bekeha Manandhar, ${ }^{5}$ Dr S unuti Rawal, Obstetrician and Gynecologist, Department of Obstertics and Gynaecology, TUTH, Kathmandu Nepal

\begin{abstract}
We report a case of Chrioangima of placenta resulting to hydropsfetalis. A 24 yrs old primigravida with polyhydramnios and large placental chorioangioma at 24 wks of gestation expelled a nonimmune hydropic male baby weighing $900 \mathrm{gms}$. The baby expired after 5 minutes of expulsion.
\end{abstract}

Keywords: Placental chorioangioma, Hydropsfetalis, Polyhydraamnios

\section{Introduction}

Placental chorioangioma is the most common benign tumor of placenta. The incidence being $1 \%$ of pregnancies. The relationship of vascularised chorioangiomas to adverse pregnancy outcome is well recognized. $50 \%$ of all cases will lead to maternal and fetal complications. Ultrasonography and Doppler ultrasonography are useful in establishing the prenatal diagnosis and the prognosis.

\section{Case Report}

A 24 yrs old primi- gravida, resident of Kathmandu was admitted in the female surgical ward on 11 chaitra 062 for observation with the diagnosis of $27+3$ weeks of gestation with chorioangioma by USG. She had 2 antenatal visit, $1^{\text {st }}$ at 18 wks, $2^{\text {nd }}$ at $26+5$ weeks of gestation. at TUTH.

She attained menarche at 14 yrs. and had regular cycle with average flow without dysmenorrhoea. Her LMP was on18.06.062 and EDD calculated to be on 25.03.063.

No family history suggestive of chorioangioma.

She was non smoker, non alcoholic. In her last ante-natal visit, at 26 weeks of gestation on examination perabdominally she was found to have uterus of 30 weeks size, it was tense in consistency with foetal parts not palpable and FHS was present. Since uterine height was more than the period of gestation urgent USG was advised keeping in mind she might have polyhydramnios, abruptio placentae, multiple pregnancy. USG revealed single live foetus of 24 week gestation with adequate liquor. And a separate placental mass measuring $8.8 \times 9 \mathrm{~cm}$ size was also noted, giving the impression of chorioangioma of placenta. So she was advised admission for observation. Next day she went into premature labour and expelled an alive male baby weighing 900 gms with Apgar score 1/10, 0/10, $0 / 10$.

Baby was cyanosed, had generalized oedema, and ascitis. There was no gross congenital anomaly.
The liver and spleen were not palpable.

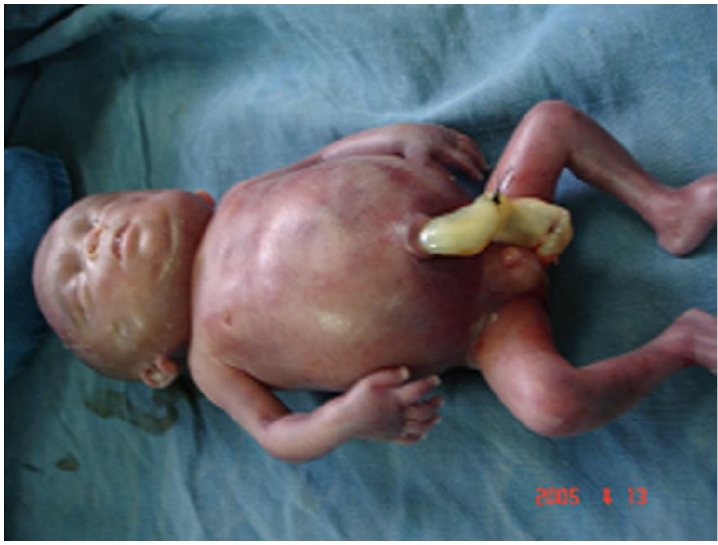

Grossly umbilical cord was $23 \mathrm{~cm}$ Placenta measured $13 \times 14 \times 5 \mathrm{~cm}$ size and was friable. There were two separate pieces of smooth brown coloured mass measuring $9 \times 10 \times 3 \mathrm{~cm} \mathrm{\&} 10 \times 60 \times 2 \mathrm{~cm}$ size, which was lobulated on the outer surface.

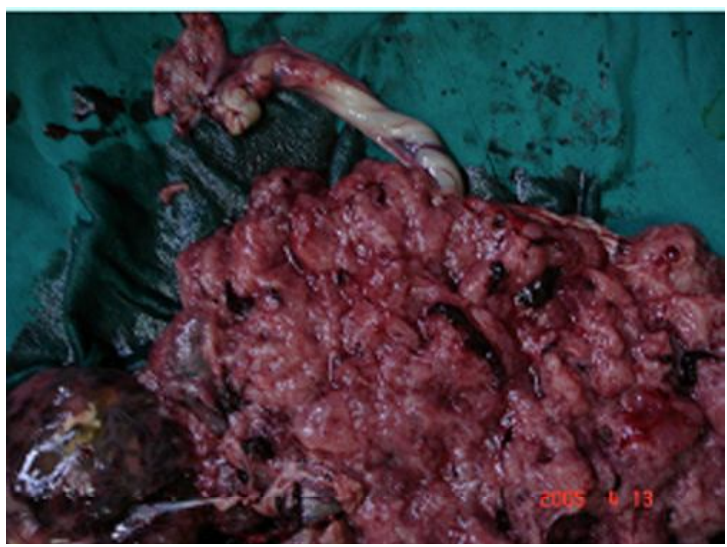

Address for correspondence: shirish.khatri@ yahoo.com 


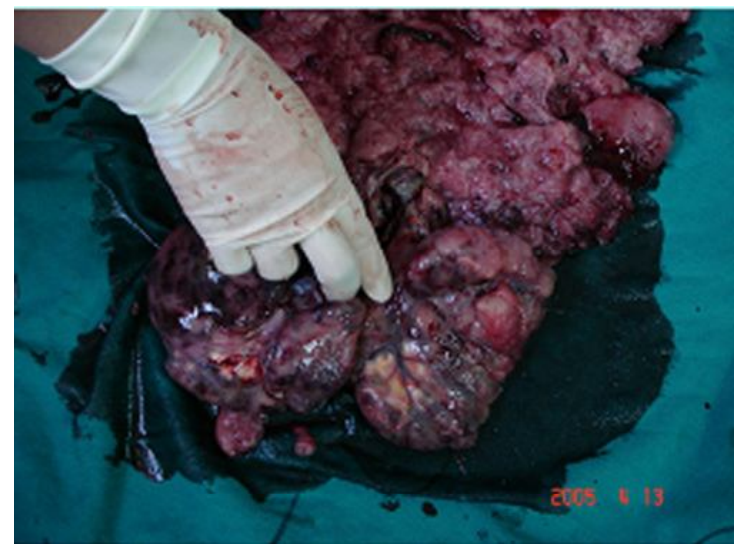

On microscopic examination section from umbilical cord showed 2 arteries \& 1 vein. Placental section showed multiple chorionic villi lined by trophoblasts with increased vascularity in the mesenchymal cone. The separate tumour mass composed mainly of small blood capillaries along with foetal myxoid area \& fibrous tissue.

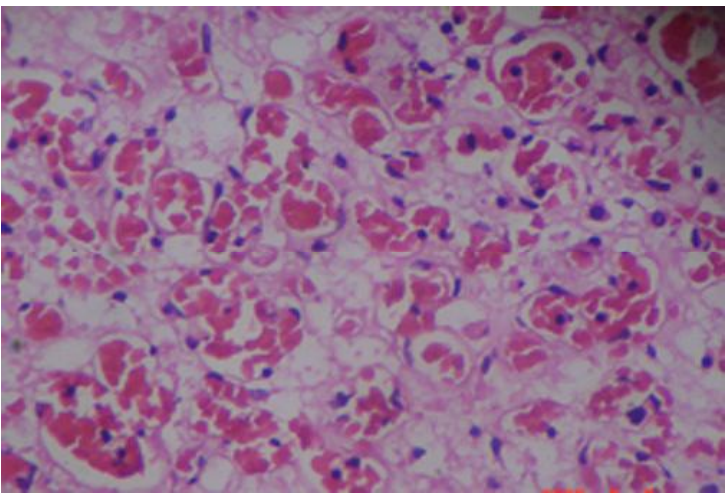

Her intranatal and post natal period was uneventful and she was discharged on $3^{\text {rd }}$ post natal day.

\section{Discussion}

Chorioangima is the most frequent non trophoblastic tumour of the placenta with a incidence ranging from $0.01-1.3 \%$ of pregnancies. This term is used to describe abnormal proliferation of vessels arising from chorionic tissue (1). It is the most common benign tumour of the placenta (2). Small placental chorioangiomas are found in $1 \%$ of pregnancies and are often of no clinical significance. Large chorioangiomas larger than $5 \mathrm{~cm}$ are much less common with an estimated incidence of 1 in 2000-3500 births, but are associated with high perinatal mortality of $40 \%$ (3). It is usually single but occasionally multiple. This case also had two placental chorioangiomas with size measuring more than $5 \mathrm{cms}$. Hpoxia and genetic factors are predisposing factors (4). The majority are small not visible on external surface are asymptomatic. It is variable in shapes and divided by fibrous septa. It most commonly protrudes from the foetal surface of the placenta near the insertion of cord. The size more than $5 \mathrm{~cm}$ is associated with complications (5).
There are multiple risk factors for chorioangioma. It is divided into moderate and high risks. Moderate risk factors include age of the patient $>35$ years, increased BP during second trimester, new paternity and dietetic factor: famine, anorexia. Environmental factors like high altitude, smoking, controlled diabetes mellitus, genetic factor.

BMI more than 25, primiparous, past family history in first degree relatives, pre-eclampsia due to premature placental release, cocaine, tobacco or caffeine use, molar pregnancy, uncontrolled diabetes mellitus, scleroderma, chronic hypertension, antiphospholipid syndrome, past history of deep vein thromosis, thrombophilia, past history of placental vascular pathology, IUFD, abruptio placentae, IUGR, repeated foetal loss, hyperhomocystinaemia are the high risk factors for chorioangioma of placenta (6). In this case clinically and by history she was not suggestive of any of the risk factors mentioned above except she was primigravida.

\section{Maternal complications includes}

Polyhydroamnios, Precipitate labour, Preeclampsia, maternal thrombocytopenia, maternal coagulopathy, Hypertonic uterus,

PROM, Haemorrhage- both APH \&PPH (6). This case had polyhydramnios, pre term premature rupture of membrane and precipitate labour.

Foetal Complication includes: Abortion due to hypoxia, IUGR, and IUD because the considerable proportion foetal blood passes through the tumour rather than the functional placental tissue. So foetus is supplied by deoxygenated blood and nutrient poor state.

There can be foetal cardiomegaly due to peripheral AV shunts leading to increased foetal cardiac output. The cause of neonatal oedema can be cardia failure or

hypoalbuminaemia - because of trasudation of protein from the surface vessels of the tumour or from chorionic foetomaternal bleeding from haemangioma.

Neonatal thrombocytopaenia is due to injury within the tumour vessels.

DIC may occur due to release of thromboplastic substance from the haemangioma. Neonatal anaemia is due to sequestration of foetal erythrocytes within the tumour, or

massive foetomaternal bleed from the haemangioma or microangiopathic haemolytic anaemia induced by injury inflicted on foetal RBC (5).

Ultrasonogram, maternal serum AFP - increased prenatally, Colour doppler imaging- to differentiate placental chorioangima from other placental lesions. colour doppler shows no blood flow within the mass, but clear foetal waveforms in its periphery can be demonstrated (7). 3D power doppler angiographyclearly shows highly vascularized placental mass including its feeding vessels\& drainage at the foetal surface of the tumour (5).

This case was diagnosed ultrasonographically which was confirmed by histopathological examination. The most effective way of diagnosing chorioangioma 
is doppler ultrasonography but we could not apply it in this case, it was planned but same night she went into preterm labour.

Various modalities of treatment of chorioangioma of placenta have been reported in different case reports.

1. Treating the cause is by occluding the vascular supply like

a. Foetoscopic devascularization by ablating the feeding vessels (8).

b. Microcoil embolization by ultrasound guided laser therapy which leads to tissue coagulation causing complete cessation of tumor blood flow (9).

c. Intravascular injection of absolute alcohol in the feeding vessels of large tumour - this may be one of the best choices due to its high efficacy, simplicity, safety and very low cost (10).

d. Ligation of tumor vessels.

2. Treating the foetal complications produced by chorioangioma prenatally by intrauterine transfusion. It is necessary if foetal anaemia is diagnosed by cordocentesis in early pregnancy. There is risk of repeated transfusion, pre-term labour and iron overload, so some form of embolization or tumour devascularization is necessary(8).

3. Symptomatic treatment like amniodrainage: when amniotic fluid index is $40 \mathrm{~cm}$, deepest pocket $12 \mathrm{~cm}$ and excessive maternal symptoms.

Prognosis is poor for large tumor. It largely depends on foetal haemodynamic tolerance with large placental chorioangioma. 50\% lead to maternal \& foetal complication (11).

\section{References}

1. Sepulveda W, Alcade J L, Schnapp C, Bravo M. Perinatal outcome after prenatal diagnosis of placental chorioangioma. J ACOG 2003;102:1028-33.

2. Napolitano R, Maruotti GM, Mazzarelli LL, Quaglia F, Tessitore G, Pecorare $M$ et al. Prenatal diagnosis of placental chorioangioma: our experience. Minerva Ginecol. 2005; 57(6): 649-54.
3. Lau TK, Leung TY, Yu SCH, To KF, Leung TN. Prenatal treatment of chorioangioma by microcoil embolization. A case reort. BJ OG 2003;110:7073.

4. Noack F, Sotlar k, Thorns C, Smreek J, Diedrich $\mathrm{K}$, Feller AC et al. VEGF-KIT protein and neural endopeptidase (NEP/CD10) - positive myofibroblasts- precursors of angiogenesis in chorioangioma? Placenta 2003; 24(7):758-66.

5. Hata T, Inubashiri E, Kanenishi K, Akiyama M, Tanaka H, Yaagihara T. Three dimensional power doppler angiographic features of placental chorioangioma. J Ultrasound Med 2004; 23:1517-20.

6. Foidart J M, S eak-San S, E monts P, Schaaps J P. Vascular placental pathology in high-risk groups: definition and synopsis. Ann Med Interne 2003; 154(5): 332-9.

7. Maymon R, Hermann G, Reish A, Strauss S, Sherman D, Heyman E. Chorioangioma and its severe infantile sequelae: case report. Prenat Diagn 2003;15(12); 976-80.

8. Witters I, Van Damme $M$, Racemakers $P$, Van Assche F, Fryns JP. Benign multiple diffuse neonatal haemangimatsis after a pregnancy complicated by polyhydramnios and a placental chorioangioma. European J ournal of Obstetrics\& Gynaecology and Reproductive Biology 2003; 106:83-85.

9. Bhide A, Perfumo $F$, Sairam $S$, Carvelho J, Thilaganathan $B$. Ultrasound guided interstitial laser therapy for the treatment 0 placental chorioangioma. Obstet Gynecol 2003;102: 118991.

10. Wanpirak C. Tongsong T, Sirichotiyakul S, Chanprapaph P. Alcoholization: the choice of intrautrine treatment for chorioangioma. J Obstet Gynaecol Res. 2002;28 (2):71-5.

11. Wehrens $X \mathrm{XH}$, Offermans J $P$, S nijders $M$, Peeters LL. Foetal cardiovascular response to large placental chorioangiomas. J Perinat Med. 2004; 32(2): 107-12. 